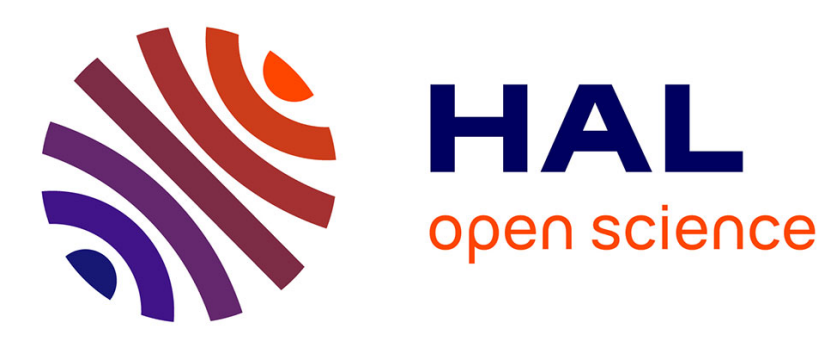

\title{
Combined effect of magnesium and amino glutamic acid on the structure of hydroxyapatite prepared by hydrothermal method
}

Sana Ben Moussa, Afef Mehri, Michel Gruselle, Patricia Beaunier, Guylene

Costentin, Béchir Badraoui

\section{To cite this version:}

Sana Ben Moussa, Afef Mehri, Michel Gruselle, Patricia Beaunier, Guylene Costentin, et al.. Combined effect of magnesium and amino glutamic acid on the structure of hydroxyapatite prepared by hydrothermal method. Materials Chemistry and Physics, 2018, 212, pp.21-29. 10.1016/j.matchemphys.2018.03.017 . hal-01741085

\section{HAL Id: hal-01741085 \\ https://hal.sorbonne-universite.fr/hal-01741085}

Submitted on 27 Mar 2018

HAL is a multi-disciplinary open access archive for the deposit and dissemination of scientific research documents, whether they are published or not. The documents may come from teaching and research institutions in France or abroad, or from public or private research centers.
L'archive ouverte pluridisciplinaire HAL, est destinée au dépôt et à la diffusion de documents scientifiques de niveau recherche, publiés ou non, émanant des établissements d'enseignement et de recherche français ou étrangers, des laboratoires publics ou privés. 


\title{
Combined effect of magnesium and amino glutamic acid on the structure of hydroxyapatite prepared by hydrothermal method
}

\author{
Sana ben Moussa ${ }^{1}$, Afef Mehri ${ }^{1}$, Michel Gruselle ${ }^{2}$ Patricia Beaunier $^{3}$, Guylène Costentin ${ }^{3}$, \\ Béchir Badraoui ${ }^{1}$
}

\begin{abstract}
${ }^{1}$ U.R. Matériaux et synthèse organique UR17ES31, Institut Préparatoire aux Etudes d'Ingénieur de Monastir, Université de Monastir, 5019 Monastir, Tunisia

${ }^{2}$ Sorbonne Université, UPMC Univ Paris 06, CNRS, UMR 8232, Institut Parisien de Chimie Moléculaire, F-75252 Paris, France

${ }^{3}$ Sorbonne Université, UPMC Univ Paris 06, CNRS, UMR 7197, Laboratoire de Réactivité de Surface, F-75252 Paris, France
\end{abstract}

\begin{abstract}
Magnesium modified calcium hydroxyapatite of different $\mathrm{Mg} / \mathrm{Ca}$ compositions have been synthesized using the hydrothermal method in the presence of glutamic acid. The resulting materials have been characterised by X-ray powder diffraction, chemical analysis, IR Spectroscopy and Transmission Electron Microscopy (TEM). X-ray diffraction analysis shows that the resulting materials consist of a single phase having an apatitic structure. IR spectroscopy highlights the presence of carboxylic groups for the organic moieties grafted onto the apatitic surface. The surface properties of apatite samples are determined.
\end{abstract}

Keywords: hydrothermal method, apatite surface, glutamic acid, hybrid compound

\section{Introduction}

Among the minerals having an interest from an economic point of view, apatites, mostly hydroxy- (CaHAp) and fluoro-apatites (FAp), are of considerable interest in numerous research areas [1-3]. Apatites are used in several applications such as sorbents, catalysts and biomaterials [4, 5]. Apatites are component of bones and teeth [6,7]. Apatites belong to the phosphate family of compounds, and are of general formula $\mathrm{M}_{10}\left(\mathrm{PO}_{4}\right)_{6} \mathrm{Y}_{2}$ where $\mathrm{M}$ is a divalent cation: $\mathrm{Ca}, \mathrm{Sr}, \mathrm{Ba}, \mathrm{Pb} \ldots$, and $\mathrm{Y}$ a hydroxyl $(\mathrm{OH})$ or halide $(\mathrm{F}, \mathrm{Cl})[8,9]$. Apatites may contain several different substituents in their structure. This ability to trap substituents in their structures leads to the formation of total or 
partial solid solutions. The substitution processes are controlled by the crystallographic rules related mainly to: ionic radius, charge, electronegativity and polarisability [10, 11]. Previous works [12-14] have shown that steric hindrance related to cations bigger in size than calcium ions, plays an important role in the limitation of the cationic substitution processes. Magnesium is undoubtedly one of the most important bivalent ions associated to biological apatites $[15,16]$. It has been verified that in calcified tissues, the amount of magnesium associated to the apatitic phase is higher at the beginning of the calcification process and decreases on increasing calcification [17-19]. This interest is increasing taking into consideration the ability of such mixed apatites to lead to hybrid organic-inorganic materials by reaction with amino-acids [20-26]. The expected benefit from the introduction of an amino-acid such as a glutamic acid in magnesium modified apatites is correlated with the ability of magnesium to coordinate amino-acids more strongly that calcium ions do and consequently to bind a greater proportion and more firmly proteins on their surfaces.

In this aim, we have carried out a structural, morphology and chemical investigation of the combined effect of magnesium and amino glutamic acid on hydroxyapatite structure. We have also studied the interaction between glutamic acid and the apatite surface. The results show that the acid forms a complex on the apatite surface. As glutamic acid functionalization should potentially modify the electrostatic interaction, the corresponding change in the surface charge of the powder was monitored by zeta-potential measurements and $\left[\mathrm{H}^{+}\right]$consumed as a function of the $\mathrm{pH}$ value.

\section{Experimental and methods}

\subsection{Synthesis}

The mixed $\mathrm{Mg} / \mathrm{CaHAp}$ of general formula: $\mathrm{Ca}_{(10-\mathrm{x})} \mathrm{Mg}_{\mathrm{x}}\left(\mathrm{PO}_{4}\right)_{6}(\mathrm{OH})_{2}(\mathrm{x}=0,0.5$ and 1.0), named $\mathrm{Ca}_{(10-\mathrm{x})} \mathrm{Mg}_{\mathrm{x}} \mathrm{HAp}$, have been synthesized using the hydrothermal method [27]. A demineralised water solution $(14 \mathrm{~mL}, 0.75 \mathrm{M})$ of a mixture of the two nitrates $\mathrm{Ca}\left(\mathrm{NO}_{3}\right)_{2} \cdot 4 \mathrm{H}_{2} \mathrm{O}$ and $\mathrm{Mg}\left(\mathrm{NO}_{3}\right)_{2} \cdot 6 \mathrm{H}_{2} \mathrm{O}$ in the desired proportions is added to a $\left(\mathrm{NH}_{4}\right)_{2} \mathrm{HPO}_{4}$ water solution $(25 \mathrm{~mL}, 0.25 \mathrm{M})$. The $\mathrm{pH}$ of the final solution is adjusted to 10 by adding a $\mathrm{NH}_{4} \mathrm{OH}$ solution $(\mathrm{d}=0.89$, Purity $=28 \%)$. The final solution is 
transferred to an autoclave. The mixture is maintained at $120^{\circ} \mathrm{C}$ for 12 hours. After filtration and

washing using hot demineralised water, the mineral is dried at $120^{\circ} \mathrm{C}$ overnight.

The hybrid materials were prepared according to the same experimental protocol, with addition of a quantity of organic reagent glutamic acid (GA) to the phosphate solution before $\mathrm{pH}$ adjustment [28]. The samples will be named as $\mathrm{Ca}_{(10-\mathrm{x})} \mathrm{Mg}_{\mathrm{x}} \mathrm{HAp}-\mathrm{GA}(n)$, where $\mathrm{n}$ is the value of the glutamic $\operatorname{acid} /(\mathrm{CaHAp})$ molar ratio $(n=10$ and 20$)$.

\subsection{Powder characterization}

$\mathrm{N}_{2}$ adsorption-desorption isotherms were performed at $77 \mathrm{~K}$ using a Micromeritics ASAP 2000 instrument. The Brunauer-Emmett-Teller equation was used to calculate the specific surface area $\left(\mathrm{S}_{\mathrm{BET}}\right)$. X-ray diffraction (XRD) analysis were carried out by means of a X'Pert Pro Panalytical X-pert diffractometer using $\mathrm{Cu}-\mathrm{K} \alpha$ radiation $\left(\lambda=1.5418 \AA\right.$, with $\theta-\theta$ geometry, equipped with an $\mathrm{X}^{\prime}$ Celerator solid detector and a Ni filter). The $2 \theta$ range was from 20 to $70^{\circ}$ with a step size $\Delta 2 \theta=0.0167^{\circ}$. The experimental patterns were compared to standards compiled by the Joint Committee on Powder Diffraction and Standards (JCPDS cards) using the X'Pert High-Score Plus software [29]. The infrared (IR) adsorption analysis of the samples were obtained using a Spectrum Two 104462 IR spectrophotometer equipped with a diamond ATR setup in the range $4000-400 \mathrm{~cm}^{-1}$. Nitrogen sorption isotherms for dried powders were recorded at $77 \mathrm{~K}$ using a sorptometer EMS-53 and KELVIN 1040/1042 (Costech International). Points of Zero Charge (PZC) and Iso-Electric Point (IPE) of the samples are determined by zeta potential measurements, using a Malvern Nano ZS. Suspensions were prepared using $\mathrm{NaCl}(0.1 \mathrm{M})$ as a background electrolyte with each powder using aqueous solutions, starting in an alkaline medium and stopping at $\mathrm{pH}=4$ under $\mathrm{N}_{2}$ at $25^{\circ} \mathrm{C}$ [30]. The titrations were carried out on suspensions of different samples of apatite obtained by adding $0.15 \mathrm{~g}$ of apatite to 30 $\mathrm{mL}$ of electrolyte $(\mathrm{NaCl})$ and then $1.5 \mathrm{~mL}$ of $0.1 \mathrm{M} \mathrm{NaOH}$. The titrant used is $0.1 \mathrm{M}$ hydrochloric acid prepared from $1 \mathrm{M} \mathrm{HCl}$, at the same ionic strength as the electrolyte by the addition of $\mathrm{NaCl}$. The phosphorus and calcium contents were obtained by ICP-OES on a Horiba Jobin Yvon modele activa. 
The thermal analysis of the carbon was carried out using a SETARAM SETSYS 1750. Heating was

performed in a platinum crucible in air flow at a rate of $10^{\circ} \mathrm{C} / \mathrm{min}$ up to $800^{\circ} \mathrm{C}$. For transmission electron microscopy (TEM) investigations, samples were prepared by dispersing the powders in a slurry of dry ethanol, deposited on a copper grid covered with a carbon thin film. High-resolution transmission electron microscopy (HRTEM) observations were performed on a JEOL JEM 2010 transmission electron microscope equipped with a $\mathrm{LaB}_{6}$ filament and operating at $200 \mathrm{kV}$. The images were collected with a 4008 X 2672 pixels CCD camera (Gatan Orius SC1000). Circular dichroism (CD) experiments were performed at solid state using $5 \mathrm{mg}$ of powder dispersed in nujol between $\mathrm{NaCl}$ pellets [31]. The measurements were performed by a TASCO J-815 spectropolarimeter. The scans were recorded from 190 to $300 \mathrm{~nm}$ wavelength with the following parameters: 0.5 data pitch, 2 $\mathrm{nm}$ bandwidth, $100 \mathrm{~nm} / \mathrm{min}$ scanning speed, and are the result of 3 accumulations.

\section{Results and discussion}

\subsection{Elemental analysis}

The results of chemical analysis for mixed CaMgHAp with glutamic acid are reported in Table 1. The CaHAp sample shows a $(\mathrm{Ca} / \mathrm{P})$ molar ratio very close to the targeted stoichiometric value of 1.67. For the apatite series, the $(\mathrm{Ca}+\mathrm{Mg} / \mathrm{P})$ ratio decreased from the starting CaHAp (1.68) to $\mathrm{Ca}_{9} \mathrm{Mg}_{1} \mathrm{HAp}-\mathrm{GA}(20)$ (1.55). The presence of the organic anion in the precipitated material is attested and quantified by the total carbon analysis. We can note the increase in carbon amount with the concentration of $\mathrm{Mg}$, this great affinity of glutamic acid to mixed $\mathrm{CaMgHAp}$ could be explained by the high electronegativity of magnesium $\left(\chi_{\mathrm{Ca}}=1, \chi_{\mathrm{Mg}}=1,31\right)$ [32], in agreement with the results previously reported for CaCuHAp modified by polyaspartic acid [33] and CaZnHAp modified by tartric acid [34]. The larger absorption of carbon in the CaMgHAp-GA would explain their loss of stoichiometry. This indicates that our samples are indeed hydroxyapatite-glutamic acid composites. For the samples CaHAp, $\mathrm{Ca}_{9.5} \mathrm{Mg}_{0.5} \mathrm{HAp}$ and $\mathrm{Ca}_{9} \mathrm{Mg}_{1} \mathrm{HAp}$ the increase in carbon amount with the 
concentration of $\mathrm{Mg}$ is explained by the disorder induced by the magnesium substitution promoting the incorporation of carbonates.

\section{Table 1}

Chemical composition (\% weight \pm 0.02 ) of grafted mixed CaMgHAp.

\begin{tabular}{lccccc}
\hline Samples & \% Ca & \% Mg & \%P & \% C & $(\mathbf{C a}+\mathbf{M g}) / \mathbf{P}$ \\
\hline $\mathrm{CaHAp}$ & 39.31 & - & 18.09 & 0.12 & 1.68 \\
$\mathrm{Ca}_{9.5} \mathrm{Mg}_{0.5} \mathrm{HA}$ & 38.14 & 0.98 & 18.66 & 0.15 & 1.65 \\
$\mathrm{p} \mathrm{Ca}_{9} \mathrm{Mg}_{1} \mathrm{HAp}$ & 35.28 & 1.82 & 18.01 & 0.18 & 1.64 \\
$\mathrm{CaHAp}-\mathrm{GA}(10)$ & 39.05 & - & 18.15 & 0.72 & 1.66 \\
$\mathrm{Ca} 9.5 \mathrm{Mg}_{0.5} \mathrm{HAp}-$ & 37.94 & 1.08 & 18.63 & 0.87 & 1.64 \\
$\mathrm{GA}(10) \mathrm{Ca}_{9} \mathrm{Mg}_{1} \mathrm{HAp}-$ & 34.05 & 1.89 & 17.98 & 1.12 & 1.59 \\
$\mathrm{GA}(10)$ & & & & & \\
$\mathrm{CaHAp}-\mathrm{GA}(20)$ & 38.97 & - & 18.23 & 1.25 & 1.65 \\
$\mathrm{Ca} 9.5 \mathrm{Mg}{ }_{0.5} \mathrm{HAp}-$ & 37.23 & 1.13 & 18.58 & 1.49 & 1.63 \\
$\mathrm{GA}(20) \mathrm{Ca} 9 \mathrm{Mg}_{1} \mathrm{HAp}-$ & 32.51 & 2.03 & 17.88 & 2.58 & 1.55 \\
$\mathrm{GA}(20)$ & & & & &
\end{tabular}

\subsection{Thermal analysis}

The (TG) curves of $\mathrm{Ca}_{9} \mathrm{Mg}_{1} \mathrm{HAp}, \mathrm{Ca}_{9} \mathrm{Mg}_{1} \mathrm{HAp}-\mathrm{GA}(10)$ and $\mathrm{Ca}_{9} \mathrm{Mg}_{1} \mathrm{HAp}-\mathrm{GA}(20)$ samples are reported in figure 1 . The thermal decomposition shows a first weight loss between $50^{\circ} \mathrm{C}$ and $200^{\circ} \mathrm{C}$, assigned to the removal of physisorbed water. The second one, between $200^{\circ} \mathrm{C}$ and $500^{\circ} \mathrm{C}$, corresponds to the elimination of the organic matter of glutamic acid. The weight loss associated with this second process allows evaluation of the relative amount of glutamic acid in the composite hybrids. The values obtained for carbon expressed as wt $\%$ of the solid product are reported in Table 2. The relative amount of glutamic acid increases with its increasing concentration in the reaction with CaHAp. This result is in agreement with the increase of the percentage of carbon determined by chemical analysis. Figure 2 reports the differential thermal analysis curves (DTA) of the samples. These curves display an unexpected endothermic effect associated with water desorption. This effect was already reported for $\mathrm{Mg}$ modified hydroxyapatites [35, 36]. It was assigned to the fact that heating in the presence of physisorbed water first induce a structuring effect. The latter may be related both to the surface relaxation at solid-water interface upon water release [37] and to 
the polarization process of $\mathrm{OH}$ groups from the columns known to occur at $200^{\circ} \mathrm{C}$ that initiates the

proton mobility inside the columns [38]. An exothermal effect is observed in the temperature range 200-500 ${ }^{\circ} \mathrm{C}$ with a peak top at $300^{\circ} \mathrm{C}$ for $\mathrm{Ca} 9 \mathrm{Mg} 1 \mathrm{HAp}-\mathrm{GA}(10)$ and $\mathrm{Ca} 9 \mathrm{Mg} 1 \mathrm{HAp}-\mathrm{GA}(20)$ samples. This peak, which is absent in the DTA plot of non-modified Ca9Mg1HAp, corresponds to the combustion of the organic material. Furthermore, the intensity of these peaks increases with increasing grafted amount content. In fact, their presence confirms that the prepared samples correspond to hydroxyapatite-glutamic acid composites, similar to that previously found for hydroxyapatite modified with glycine and sarcosine acids [39].

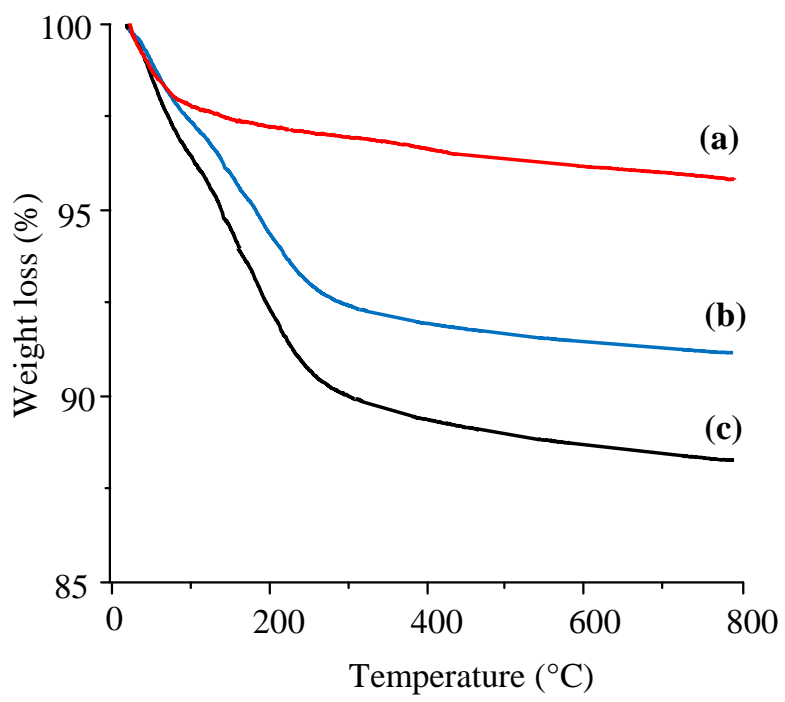

Fig. 1. TG plots; (a) $\mathrm{Ca}_{9} \mathrm{Mg}_{1} \mathrm{HAp}$, (b) $\mathrm{Ca}_{9} \mathrm{Mg}_{1} \mathrm{HAp}$ $-\mathrm{GA}(10)$ and (c) $\mathrm{Ca}_{9} \mathrm{Mg}_{1} \mathrm{HAp}-\mathrm{GA}(20)$.

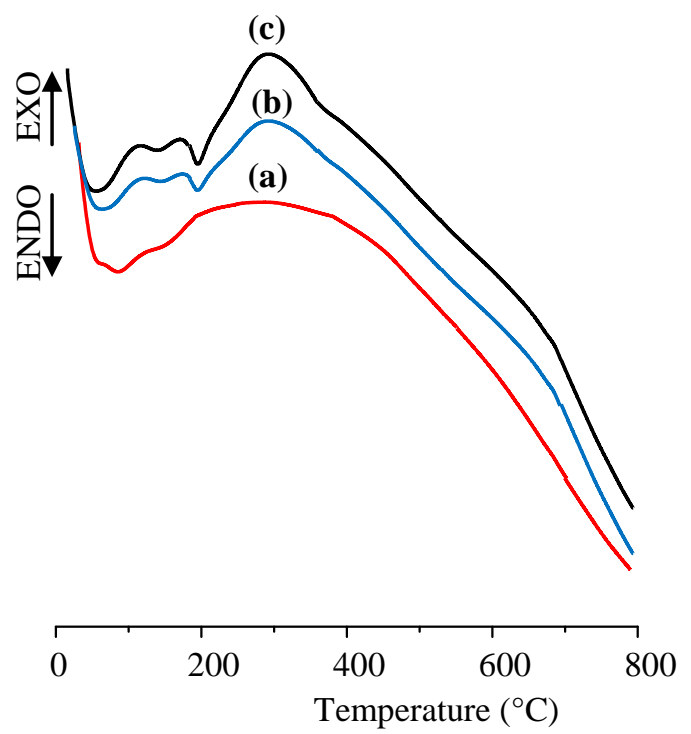

Fig. 2. DTA plots; (a) $\mathrm{Ca}_{9} \mathrm{Mg}_{1} \mathrm{HAp}$, (b) $\mathrm{Ca}_{9} \mathrm{Mg}_{1} \mathrm{HAp}-\mathrm{GA}(10)$ and (c) $\mathrm{Ca}_{9} \mathrm{Mg}_{1} \mathrm{HAp}-\mathrm{GA}(20)$.

\section{Table 2}

Results of TG analysis of ungrafted and grafted apatites.

\begin{tabular}{|c|c|c|}
\hline Samples & $\begin{array}{l}\text { First loss }(\% \mathrm{wt}): \\
\text { water } \quad\left(50-200^{\circ} \mathrm{C}\right)\end{array}$ & $\begin{array}{l}\text { Second } \operatorname{loss}(\% \mathrm{wt}) \text { : glutamic } \\
\text { acid }\left(200-500^{\circ} \mathrm{C}\right)\end{array}$ \\
\hline $\mathrm{Ca}_{9} \mathrm{Mg}_{1} \mathrm{HAp}$ & 2.5 & 1.3 \\
\hline $\mathrm{Ca}_{9} \mathrm{Mg}_{1} \mathrm{HAp}-\mathrm{GA}(10)$ & 3.4 & 4.6 \\
\hline $\mathrm{Ca}_{9} \mathrm{Mg}_{1} \mathrm{HAp}-\mathrm{GA}(20)$ & 4.8 & 6.7 \\
\hline
\end{tabular}

\subsection{Circular dichroism}


In figure 3 (left) are presented the dichroic curves obtained in the range 300-190 nm for

glutamic acid (a) and $\mathrm{Ca}_{9} \mathrm{Mg}_{1} \mathrm{HAp}-\mathrm{GA}(20)$ (b) respectively. The two curves are very close to each other showing a negative maximum at $200 \mathrm{~nm}$ for $\mathrm{GA}$ and $230 \mathrm{~nm}$ for $\mathrm{Ca}_{9} \mathrm{Mg}_{1} \mathrm{HAp}-\mathrm{GA}(20)$. The corresponding UV absorption curves on the right are also very similar. The negative effect at $200 \mathrm{~nm}$ is also observed in water solution for glutamic acid oligomers [40]. The $30 \mathrm{~nm}$ difference observed between the curves (a) and (b) can be related to the difference in ionisation of the carboxylic group of adsorbed or free glutamic acid.
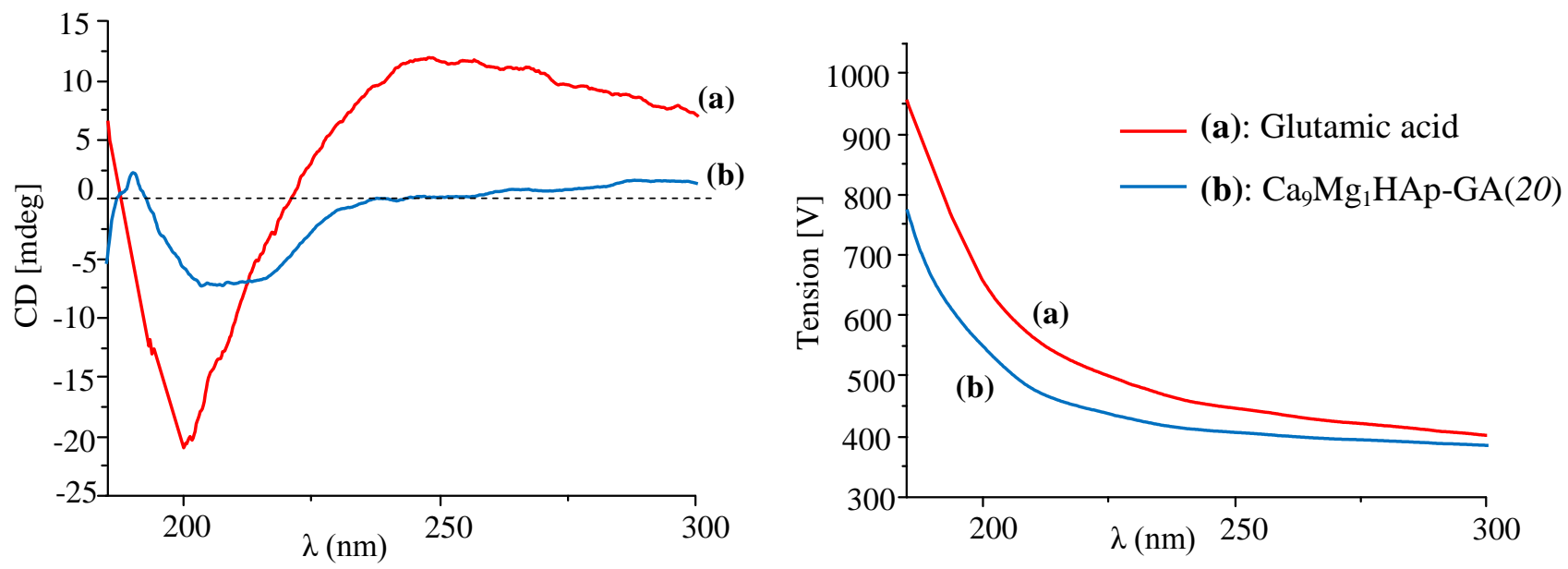

Fig. 3. (Left) Circular dichroism spectrum and (right) UV absorption curves of (a) glutamic acid and (b) $\mathrm{Ca}_{9} \mathrm{Mg}_{1} \mathrm{HAp}-\mathrm{GA}(20)$.

\subsection{Infrared investigation}

The IR spectra recorded with or without glutamic acid onto the apatite surface are illustrated in figure 4 . The vibrations in the range $1800-1200 \mathrm{~cm}^{-1}$ are summarized in table 3 . In particular, the bands observed at 1598,1445 and $1261 \mathrm{~cm}^{-1}$ (Fig. 4b, 4c), which are not present in the spectrum of $\mathrm{Ca}_{9} \mathrm{Mg}_{1} \mathrm{HAp}$ (Fig. 4a) can be attributed to sorbed glutamic acid [41]. The vibration located at $1635 \mathrm{~cm}^{-}$ ${ }^{1}$ is attributed to adsorbed water [42]. The higher water content in the presence of glutamic acid is consistent with the decrease in the ratio $(\mathrm{Ca}+\mathrm{Mg}) / \mathrm{P}$. In order, to eliminate the hypothesis of a simple mechanical mixture between glutamic acid and apatite, further data have been recorded from such 
mixture containing $\mathrm{Ca}_{9} \mathrm{Mg}_{1} \mathrm{HAp}$ and glutamic acid in the same relative amounts as those contained in

the $\mathrm{Ca}_{9} \mathrm{Mg}_{1} \mathrm{HAp}-\mathrm{GA}(20)$ sample. The FT-IR spectrum of this mixture, which is reported in Fig. $4 \mathrm{~d}$, displays a number of bands due to the two discrete components of the mixture, and indicates the absence of specific interaction between the carboxylic groups of the glutamic acid and the calcium ions of hydroxyapatite. The comparison with the spectra reported in Fig. $4 \mathrm{~b}$ and $4 \mathrm{c}$, which show also a small shift of the carboxylic stretching band to lower wave numbers, in agreement with an increase of the $\mathrm{C}-\mathrm{O}$ bond length can be attributed to those of the organic moieties grafted on calcium or magnesium atoms on the surface of the hydroxyapatite, in agreement with the results previously reported for CaHAp modified by amino-acids [39, 43].

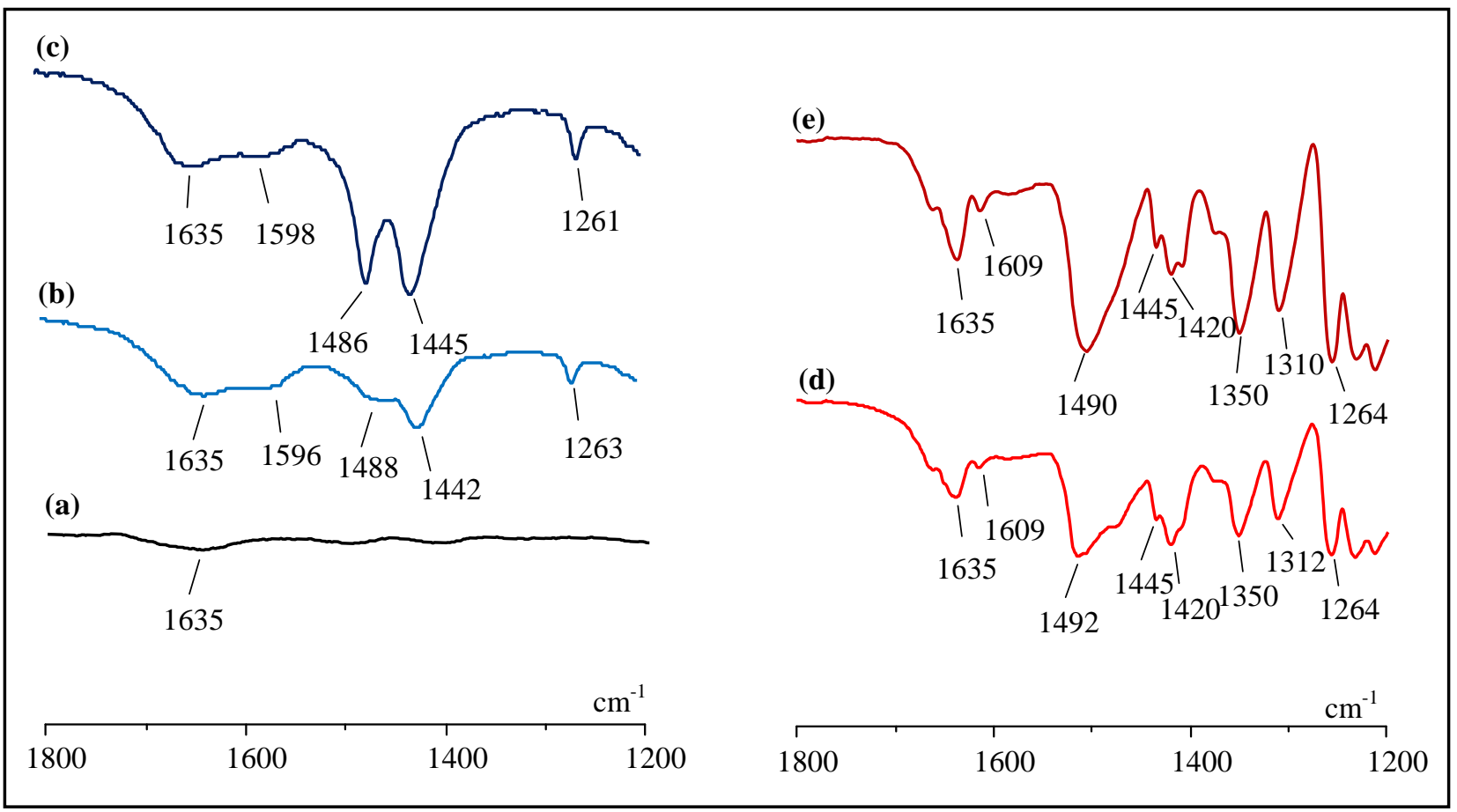

Fig. 4. FT-IR spectra of: (a) $\mathrm{Ca}_{9} \mathrm{Mg}_{1} \mathrm{HAp}$, (b) $\mathrm{Ca}_{9} \mathrm{Mg}_{1} \mathrm{HAp}-\mathrm{GA}(10)$, (c) $\mathrm{Ca}_{9} \mathrm{Mg}_{1} \mathrm{HAp}-\mathrm{GA}(20)$, (d) Mixed $\mathrm{Ca}_{9} \mathrm{Mg}_{1} \mathrm{HAp}$-glutamic acid and (e) glutamic acid.

Table 3

FTIR Spectral data $( \pm 5)$ of $\mathrm{Ca}_{9} \mathrm{Mg}_{1} \mathrm{HAp}-\mathrm{GA}(10), \mathrm{Ca}_{9} \mathrm{Mg}_{1} \mathrm{HAp}-\mathrm{GA}(20)$, and pure glutamic acid. Wave number $\left(\mathrm{cm}^{-1}\right)$

Tentative assignments

Glutamic acid [41] $\mathrm{Ca}_{9} \mathrm{Mg}_{1} \mathrm{HAp}-\mathrm{GA}(10) \quad \mathrm{Ca}_{9} \mathrm{Mg}_{1} \mathrm{HAp}-\mathrm{GA}(20)$

COO- asym.str.

1609

1596

1598


$\mathrm{CH}_{2}$ str.

Amide III

Asym.: Asymmetrical, str.: stretching

\subsection{X-ray analysis}

The X-ray powder diffractograms for CaHAp and $\mathrm{Ca}_{9} \mathrm{Mg}_{1} \mathrm{HAp}$ synthesized with or without the presence of glutamic acid are shown in figure 5. In table 4, we reported the size of the apatite crystallites induced by magnesium and glutamic acid for the reflections (002) and (310). For all samples, we observe a unique apatitic phase belonging to the $\mathrm{P}_{3} / \mathrm{m}$ space group $\left(\mathrm{n}^{\circ}\right.$ 9-432-ICDDPDF). We could not prepare the grafted apatites $\mathrm{Ca}_{8.5} \mathrm{Mg}_{1.5} \mathrm{HAp}-\mathrm{GA}(n)$, since all our preparations failed. Several authors have shown that the particular behavior of the $\mathrm{Ca}_{8.5} \mathrm{Mg}_{1.5} \mathrm{HAp}$ compound can therefore be explained by the fact that sample $\mathrm{Ca}_{8.5} \mathrm{Mg}_{1.5} \mathrm{HAp}$ is a pure non stoichiometric $\mathrm{CaMgHAp}$ which would turn into whitlockite under the effect of temperature and already made up of a mixture of phases CaMgHAp crystalline and amorphous whitlockite $\left[\mathrm{Ca}_{3-y} \mathrm{Mg}_{\mathrm{y}}\left(\mathrm{HPO}_{4}\right)_{z}\left(\mathrm{PO}_{4}\right)_{2-2 \mathrm{z} / 3}\right]$, which is crystallized under the effect of heat treatment at $900{ }^{\circ} \mathrm{C}[44,45]$.

Broadening of the diffraction lines increases with the concentration of magnesium and glutamic acid. The crystallite sizes were calculated from the broadening of the $\left(\begin{array}{lll}0 & 0 & 2\end{array}\right)$ and $\left(\begin{array}{lll}3 & 1 & 0\end{array}\right)$ using the Scherrer equation [46]: $D \quad \frac{K \lambda}{\beta_{1 / 2} \cos \theta}$

Where $\theta$ is the diffraction angle, $\lambda$ the wavelength and $K$ a constant depending on the crystal (chosen as 0.9 for apatite crystallites) and $\beta_{1 / 2}$ is the line width at full width at half maximum (FWHM), of a given reflection. The line broadening of the $\left(\begin{array}{lll}0 & 0 & 2\end{array}\right)$ and $\left(\begin{array}{lll}3 & 1 & 0\end{array}\right)$ reflections was used to evaluate the crystallite size along the $c$-axis and along a direction perpendicular to it. The crystallinity (Xc) is defined as the fraction of the crystalline apatite phase in the investigated volume of powdered sample. An empirical relation between $X_{c}$ and $\beta_{1 / 2}$ was deduced, according to the following equation [47]: $X_{c}=$ $\left[\mathrm{K}_{\mathrm{A}} / \beta_{1 / 2}\right]^{3}$. Where $K_{A}$ is a constant set at 0.24 and $\beta_{1 / 2}$ is the FWHM of the $\left(\begin{array}{lll}0 & 0 & 2\end{array}\right)$ reflection, the 
obtained values are reported in Table 4. The crystallite size and the crystallinity decrease with

increasing magnesium and amino acid concentration. It can also be deduced that the crystallites are of nanometric sizes and the decrease is more important in the $\left(\begin{array}{lll}3 & 1 & 0\end{array}\right)$ than in the $\left(\begin{array}{lll}0 & 0\end{array}\right)$ direction. Such observation was earlier reported for other organic moieties grafted onto apatite surfaces and can be explained by a better interaction of the glutamic acid with faces parallel to the $\mathrm{c}$ axis $[48,33]$.

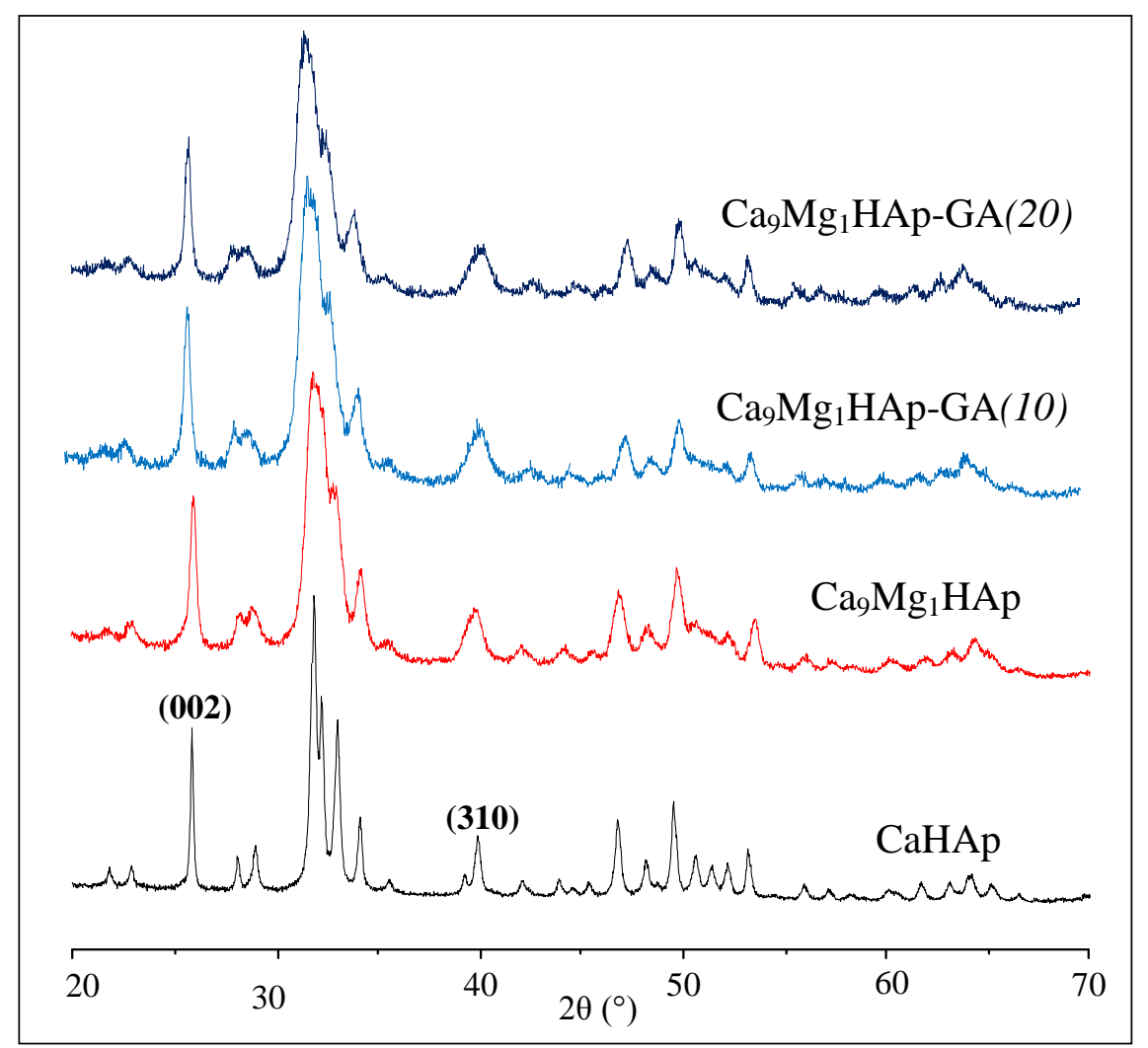

Fig. 5. X-ray diffractograms for $\mathrm{CaHAp}$ and $\mathrm{Ca}_{9} \mathrm{Mg}_{1} \mathrm{HAp}$ ungrafted and grafted.

The individual effect of magnesium and glutamic acid on the crystallite size can be observed in figure 6. The crystallite sizes $\mathrm{D}_{(002)}$ and $\mathrm{D}_{(310)}$ decrease slowly with the concentration of magnesium whereas the addition of glutamic acid induces a bigger change in the crystallinity. It would appear that the glutamic acid is the component most responsible for the loss of crystallinity which could be explained by the presence of the groups $\mathrm{COO}^{-}$on the surface of materials. We do not observe a change in position of the peaks between CaHAp and $\mathrm{Ca}_{9} \mathrm{Mg}_{1} \mathrm{HAp}$ diffractograms, here the main phenomenon is the broadning of the peaks, which has already been observed during the substitution of calcium by 
another divalent ion. When glutamic acid is present, we observe no difference between $\mathrm{Ca}_{9} \mathrm{Mg}_{1} \mathrm{HAp}$ -

$\mathrm{GA}(10)$ and $\mathrm{Ca}_{9} \mathrm{Mg}_{1} \mathrm{HAp}-\mathrm{GA}(20)$ diffractograms. In contrast, peak shifts are observed compared to the CaHAp and $\mathrm{Ca}_{9} \mathrm{Mg}_{1} \mathrm{HAp}$ one, in particular for the (211) and (222) peaks. This phenomenon that we have already described was attributed to a better interaction of the glutamic acid with the faces parallel to the axis c during the process of crystalline growth [39].

Table 4: Evolution size of the apatite crystallites with magnesium and glutamic acid for the reflexion (002) and (310).

\begin{tabular}{llllll}
\hline Samples & $\left.\boldsymbol{\beta}_{\mathbf{1 / 2}} \mathbf{( 0 0 2}\right)$ & $\mathbf{D}_{(\mathbf{0 0 2})}(\mathbf{A})$ & $\left.\boldsymbol{\beta}_{\mathbf{1 / 2}} \mathbf{( 3 1 0}\right)$ & $\mathbf{D}_{(\mathbf{3 1 0})}(\mathbf{\AA})$ & Crystallinity $\left(\mathbf{X}_{\mathbf{C}}\right)$ \\
\hline $\mathrm{CaHAp}$ & $0.191(1)$ & 427 & $0.477(9)$ & 177 & 1.981 \\
$\mathrm{Ca} 9.5 \mathrm{Mg}_{0.5} \mathrm{HAp}$ & $0.207(2)$ & 394 & $0.640(1)$ & 132 & 1.554 \\
$\mathrm{Ca}{ }_{9} \mathrm{Mg}_{1} \mathrm{HAp}$ & $0.264(2)$ & 309 & $0.712(1)$ & 119 & 0.749 \\
& & & & & \\
$\mathrm{CaHAp}-\mathrm{GA}(10)$ & $0.230(4)$ & 354 & $0.710(4)$ & 119 & 1.042 \\
$\mathrm{Ca}_{9.5} \mathrm{Mg}_{0.5} \mathrm{HAp}-\mathrm{GA}(10)$ & $0.283(4)$ & 288 & $0.931(3)$ & 91 & 0.607 \\
$\mathrm{Ca}{ }_{9} \mathrm{Mg}_{1} \mathrm{HAp}-\mathrm{GA}(10)$ & $0.364(5)$ & 224 & $1.286(3)$ & 66 & 0.285 \\
& & & & & \\
$\mathrm{CaHAp}-\mathrm{GA}(20)$ & $0.233(1)$ & 350 & $0.761(2)$ & 111 & 1.029 \\
$\mathrm{Ca}{ }_{9.5} \mathrm{Mg}_{0.5} \mathrm{HAp}-\mathrm{GA}(20)$ & $0.322(3)$ & 253 & $1.084(1)$ & 75 & 0.413 \\
$\mathrm{Ca} \mathrm{Mg}_{1} \mathrm{HAp}-\mathrm{GA}(20)$ & $0.389(2)$ & 210 & $1.385(1)$ & 61 & 0.234
\end{tabular}

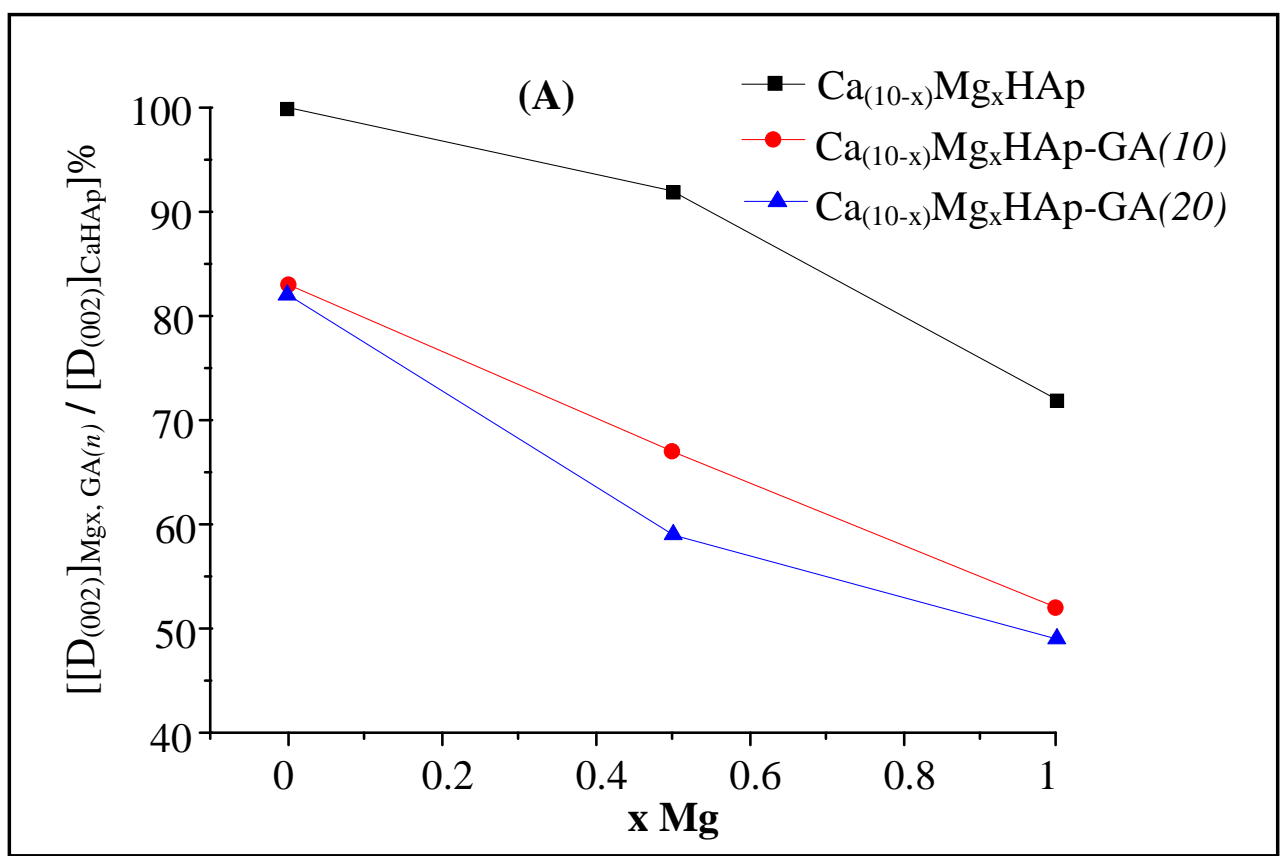




\subsection{TEM observations}

Transmission electron microscopy (TEM) analysis micrographs of the samples are illustrated in figure 7A. From the photomicrographs, it can be seen that the size of precipitated apatite particles, prepared with and without glutamic acid, is on the nanometer scale. CaHAp is constituted of well dispersed plate-shaped crystals with an average size of about 40-150 nm long and about $30 \mathrm{~nm}$ wide. A small addition of magnesium induces a decrease of the size: 30-60 nm long and about 15-20 nm wide for the $\mathrm{Ca}_{9.5} \mathrm{Mg}_{0.5} \mathrm{HAp}$. The presence of magnesium and glutamic acid in the start solution completely modifies the aspect. We obtain large bundles of CaMgHAp-GA fibers (300 nm length /80 $\mathrm{nm}$ width). The HRTEM images (Fig. 7B) reveal that theses fibers are thin (15 $\mathrm{nm}$ wide) and stacked together to each other. The analysis of the FFT patterns show that the growth of the particles always occurs in the (002) direction, indicating that they are growing along the $\mathrm{c}$ axis direction such as the 
pure CaHAp. The results of the TEM analysis confirm that the apatite structure is preserved with a

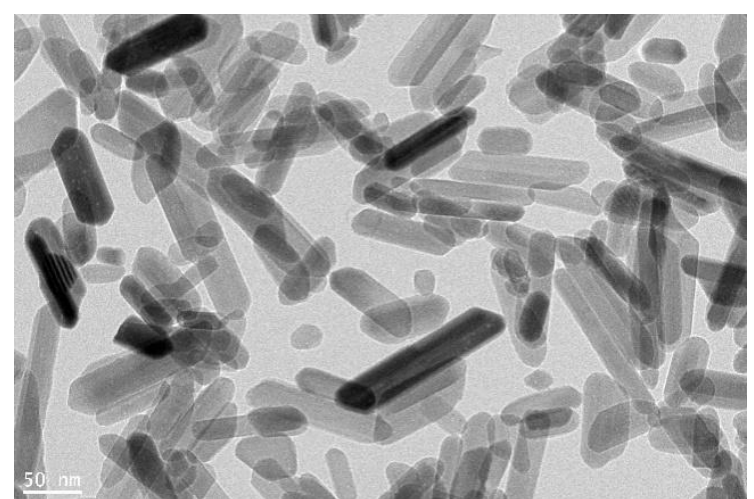

CaHAp

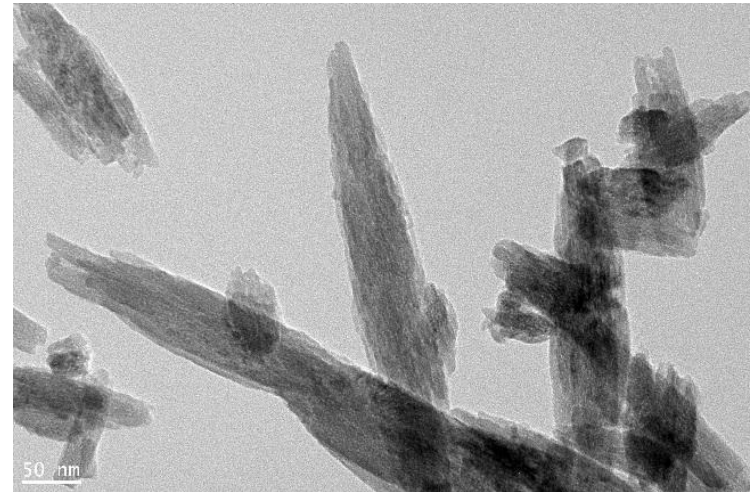

$\mathrm{Ca}_{9} \mathrm{Mg}_{1} \mathrm{HAp}-\mathrm{GA}(10)$

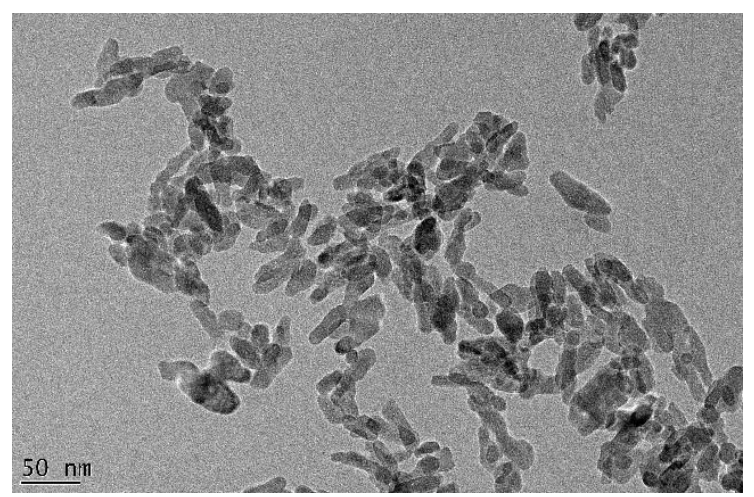

$\mathrm{Ca}_{9.5} \mathrm{Mg}_{0.5} \mathrm{HAp}$

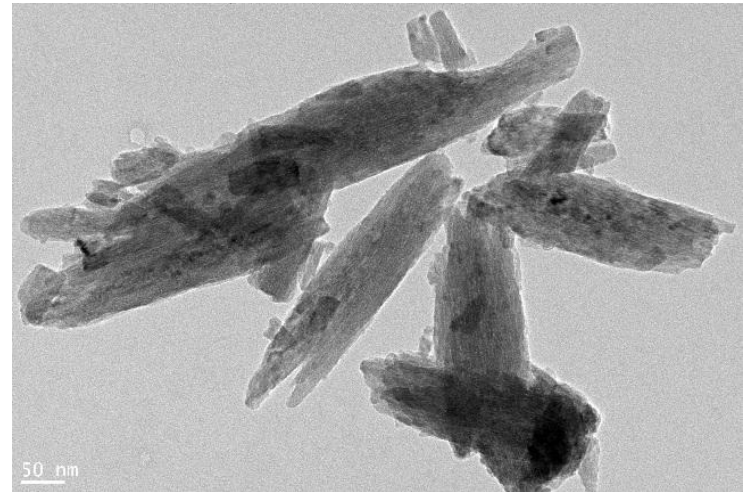

$\mathrm{Ca}_{9} \mathrm{Mg}_{1} \mathrm{HAp}-\mathrm{GA}(20)$

Fig. 7A. TEM images (Scale bars $=50 \mathrm{~nm}$ ) of CaHAp, $\mathrm{Ca}_{9.5} \mathrm{Mg}_{0.5} \mathrm{HAp}, \mathrm{Ca}_{9} \mathrm{Mg}_{1} \mathrm{HAp}-\mathrm{GA}(10)$ and $\mathrm{Ca}_{9} \mathrm{Mg}_{1} \mathrm{HAp}-\mathrm{GA}(20)$.

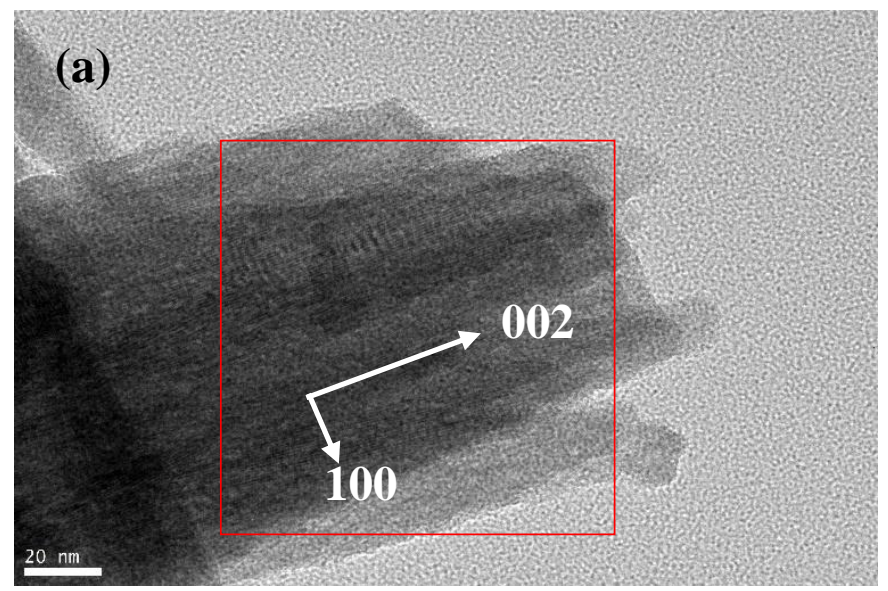

$\mathrm{Ca}_{9} \mathrm{Mg}_{1} \mathrm{HAp}-\mathrm{GA}$ (10)

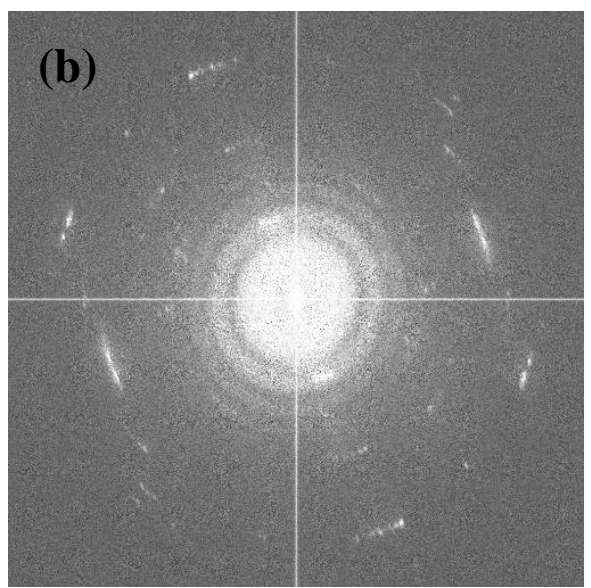

$\mathrm{Ca}_{9} \mathrm{Mg}_{1} \mathrm{HAp}-\mathrm{GA}$ (10) 


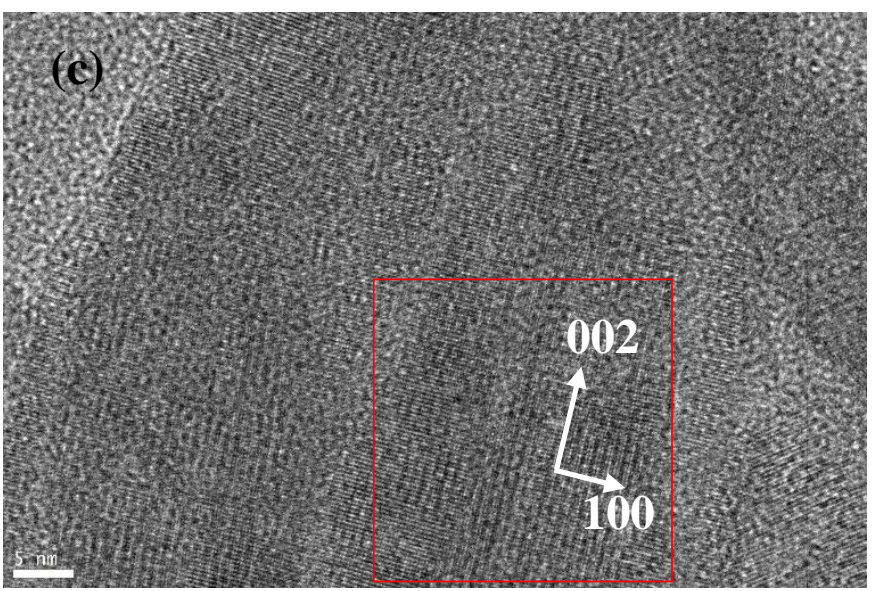

$\mathrm{Ca}_{9} \mathrm{Mg}_{1} \mathrm{HAp}-\mathrm{GA}(20)$

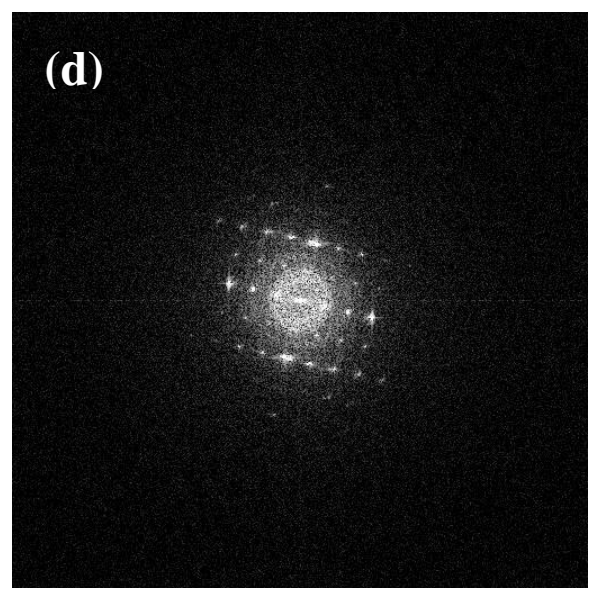

$\mathrm{Ca}_{9} \mathrm{Mg}_{1} \mathrm{HAp}-\mathrm{GA}(20)$

Fig. 7B. HRTEM images and FFT patterns of the selected area: (a, b) $\mathrm{Ca}_{9} \mathrm{Mg}_{1} \mathrm{HAp}-\mathrm{GA}(10)$ and (c, d) $\mathrm{Ca} 9 \mathrm{Mg}_{1} \mathrm{HAp}-\mathrm{GA}(20)$.

\subsection{Functionalization of CaHAp with glutamic acid}

\subsubsection{Speciation of the interface apatite-solution}

The influence of the glutamic acid amount on the textural properties of CaHAp was examined (Table 5). We obtained $43 \mathrm{~m}^{2} / \mathrm{g}$ for $\mathrm{Ca}_{9} \mathrm{Mg}_{1} \mathrm{HAp}$ and after functionalization $30 \mathrm{~m}^{2} / \mathrm{g}$ and 24 $\mathrm{m}^{2} / \mathrm{g}$ for $\mathrm{Ca}_{9} \mathrm{Mg}_{1} \mathrm{HAp}-\mathrm{GA}(10)$ and $\mathrm{Ca}_{9} \mathrm{Mg}_{1} \mathrm{HAp}-\mathrm{GA}(20)$, respectively. The decrease in the specific surface area of the apatite samples is related to the structural arrangement of the 2-aminopentanedioic acid on the surface of the solid. These results are in good agreement with those obtained by Oberto Da Silva et al. [49]. The initial $\mathrm{pH}_{\mathrm{i}}$ value measured in aqueous solutions increase with the glutamic acid ratio. We recorded 8.9 and 9.3 for $\mathrm{Ca}_{9} \mathrm{Mg}_{1} \mathrm{HAp}-\mathrm{GA}(10)$ and $\mathrm{Ca}_{9} \mathrm{Mg}_{1} \mathrm{HAp}-\mathrm{GA}(20)$ respectively against only 8.4 for $\mathrm{Ca}_{9} \mathrm{Mg}_{1} \mathrm{HAp}$.

\section{Table 5}

Surface area and $\mathrm{pH}$ value of different apatite samples

\begin{tabular}{llllc}
\hline Samples & $\mathbf{S}_{\text {BET }}\left(\mathbf{m}^{2} / \mathbf{g}\right)$ & IEP & PZC & $\mathbf{p H}_{\mathbf{i}}$ in aqueous solution \\
\hline $\mathrm{Ca}_{9} \mathrm{Mg}_{1} \mathrm{HAp}$ & 43 & 7.1 & 8.2 & 8.4 \\
$\mathrm{Ca}_{9} \mathrm{Mg}_{1}$ Hap-GA(10) & 30 & 8.2 & 8.6 & 8.9 \\
$\mathrm{Ca}_{9} \mathrm{Mg}_{1}$ Hap-GA(20) & 24 & 8.6 & 8.8 & 9.3 \\
\hline
\end{tabular}

PZC: point zero charge is determined by an acid-basic titration equilibrated at $16 \mathrm{~h}$ IEP: Iso-electric point $(\mathrm{mV})$ is determined by zeta-metry 
The Zeta potential of different apatite samples is presented in figure 8. The values of Point of

Zero Charge (PZC) and iso-electric point (IEP) were determined (Table 5). In a basic medium, the $\mathrm{Ca}_{9} \mathrm{Mg}_{1} \mathrm{HAp}$ sample is characterized by a highly negative zeta potential indicating a deficit of positive surface charge, a value lower than that of the apatites $\mathrm{Ca}_{9} \mathrm{Mg}_{1} \mathrm{HAp}-\mathrm{GA}(10)$ and $\mathrm{Ca}_{9} \mathrm{Mg}_{1} \mathrm{HAp}-\mathrm{GA}(20)$. This result indicates an increase in positive surface charge sites, on amino-acid grafted apatites [50].

Whereas the value of $\mathrm{pH}_{\text {IEP }}$ is 7.1, the $\mathrm{PZC}$ for the $\mathrm{Ca}_{9} \mathrm{Mg}_{1} \mathrm{HAp}$ sample is around 8.2. The same value is found in the literature [51-54] (Figure 8(B)). This result can be explained by the presence of initial charge and specific adsorption at the surface of apatite. After glutamic acid functionalization, the Zeta-potential curve is shifted towards alkaline $\mathrm{pH}$ values, with $\mathrm{pH}_{\mathrm{IEP}}$ of 8.2 and 8.6 for $\mathrm{Ca}_{9} \mathrm{Mg}_{1} \mathrm{HAp}-\mathrm{GA}(10)$ and $\mathrm{Ca}_{9} \mathrm{Mg}_{1} \mathrm{HAp}-\mathrm{GA}(20)$, respectively. This result verified by measurement of PZC (from 8.6 to 8.8), confirms the functionalization of the surface of $\mathrm{Ca}_{9} \mathrm{Mg}_{1} \mathrm{HAp}$ by the glutamic acid.

The total number of protons consumed during titrations of different samples is determined using this equation:

$$
\left[\mathrm{H}^{+}\right]_{\mathrm{S}}=\frac{1}{\mathrm{~S}_{\exp }}\left(\frac{\left.\left(\mathrm{C}_{\mathrm{a}} \mathrm{V}_{\mathrm{a}}-\mathrm{C}_{\mathrm{b}} \mathrm{V}_{\mathrm{b}}\right)_{\text {susp }}-\left(\mathrm{C}_{\mathrm{a}} \mathrm{V}_{\mathrm{a}}-\mathrm{C}_{\mathrm{b}} \mathrm{V}_{\mathrm{b}}\right)_{\text {blanc }}\right)}{\mathrm{V}}-\frac{10^{-\mathrm{pH}}}{\gamma_{\mathrm{H}^{+}}}+\frac{10^{-(-\mathrm{Log}(\mathrm{Ke})-\mathrm{pH})}}{\gamma_{\mathrm{OH}^{-}}}\right)
$$

$S_{\text {exp }}$ : specific surface area $\left(\mathrm{m}^{2} / g\right)$ exposed in the suspension, $V$ is total volume of solution; $C_{a}$ and $C_{b}$ are the $\mathrm{HCl}$ and $\mathrm{NaOH}$ concentration used for titration. $\mathrm{K}_{\mathrm{e}}$ is the dissociation constant of water. $\left.\gamma_{(\mathrm{H}+}\right)$ and $\gamma(\mathrm{OH}-)$ are the coefficient of the dissociation activity of $\mathrm{H}^{+}$and $\mathrm{OH}^{-}$calculated by Debye-Huckel relation. $\log \left(\gamma_{i}\right)=-\left(z_{i}\right)^{2} \mathrm{D}$

With $\mathrm{Z}_{\mathrm{i}}$ is the ion charge and $\mathrm{D}=\frac{\mathrm{A} \sqrt{\mathrm{I}}}{1+\mathrm{B} \alpha_{\mathrm{i}}^{0} \sqrt{\mathrm{I}}}$ 
I: Ionic strength of solution (mol/L), $A=0.507, B=0.328 .10^{-8}$ and $\alpha_{i}^{0}$ is the effective diameter (Fig.

$8(\mathbf{B}))$. This quantity of protons $\left(\mathrm{H}^{+}\right)$is deduced from the difference between the amount of $\left(\mathrm{H}^{+}\right)$added to the suspension and the amount of free $\left(\mathrm{H}^{+}\right)$in solution. This is calculated directly from the measured $\mathrm{pH}$. The amount of the added protons is corrected by the amount of hydroxyl initially added to the suspension.

The proton quantity consumed by apatite samples $\left[\mathrm{H}^{+}\right]$shows the same evolution: in an acid medium, $\left[\mathrm{H}^{+}\right]$is between 9 and $12 \mu \mathrm{mol} / \mathrm{m}^{2}(\mathrm{pH}=5)$ for $\mathrm{Ca}_{9} \mathrm{Mg}_{1} \mathrm{HAp}, \mathrm{Ca}_{9} \mathrm{Mg}_{1} \mathrm{HAp}-\mathrm{GA}(10)$ and $\mathrm{Ca}_{9} \mathrm{Mg}_{1} \mathrm{HAp}-\mathrm{GA}(20)$, respectively. Then, it decreases regularly and becomes negative in a basic medium with the protons consumed in the order of -8 and $-10 \mu \mathrm{mol} / \mathrm{m}^{2}$ at $\mathrm{pH}=11$.

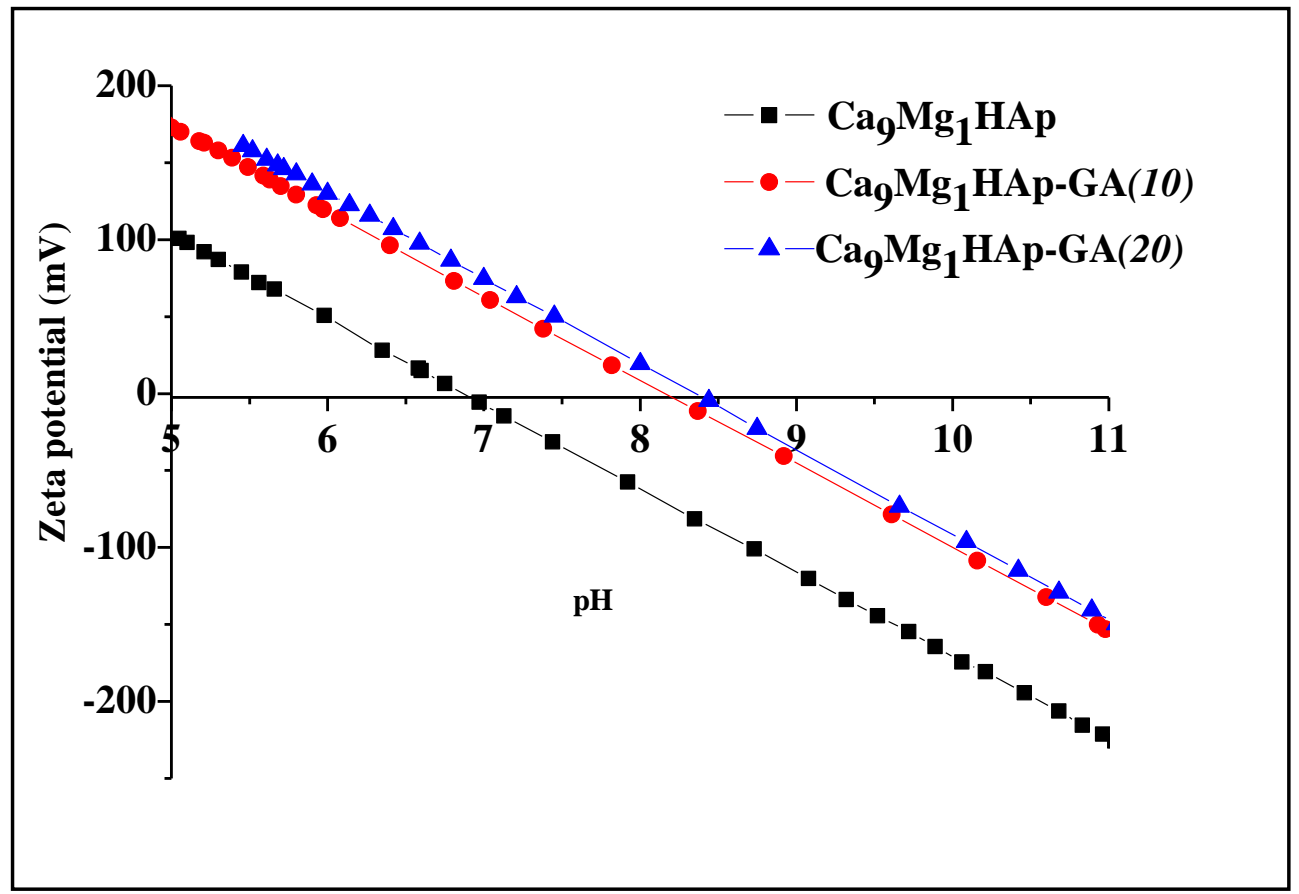




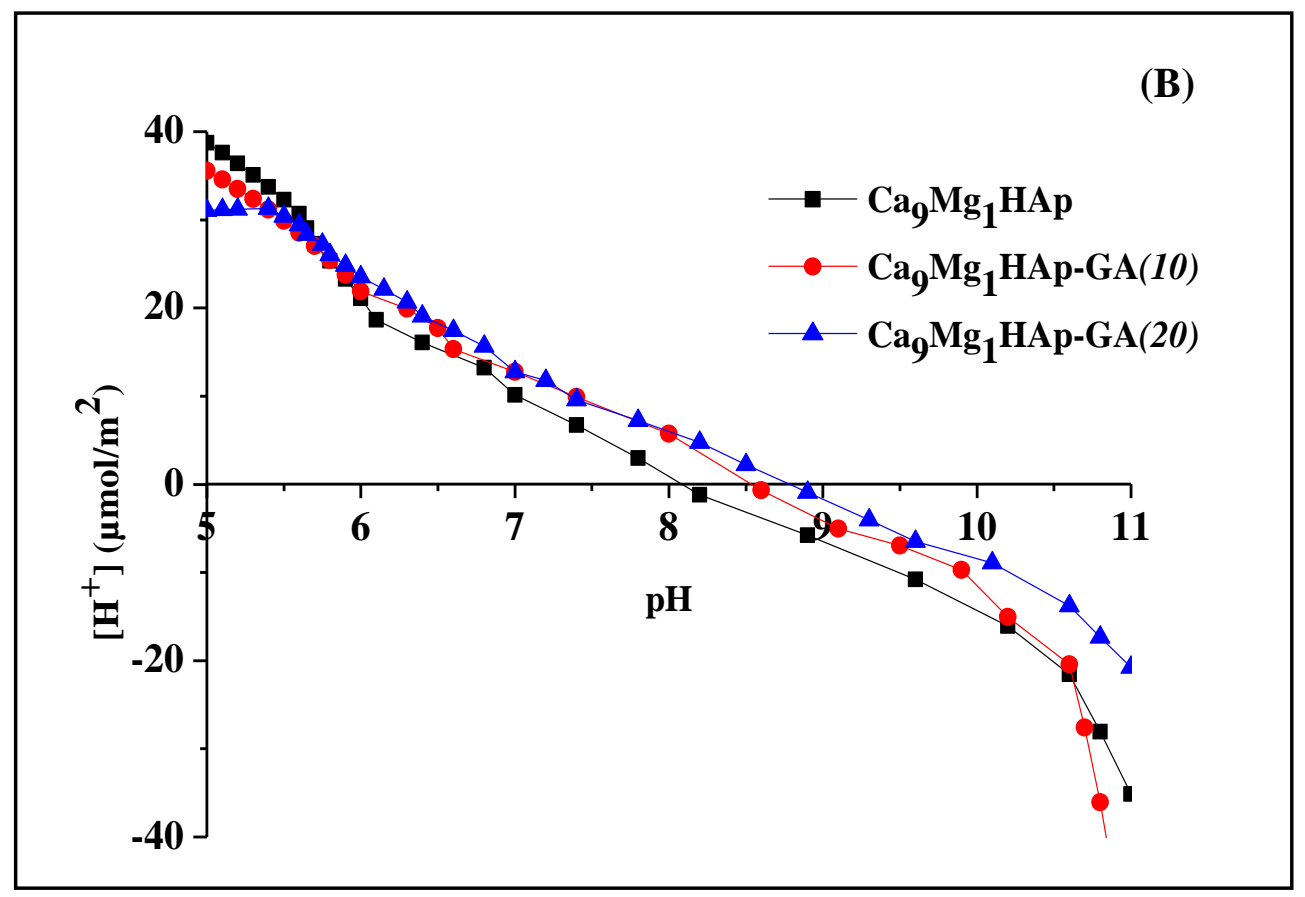

Fig. 8. (A) Zeta potential IEP (in $\mathrm{mV}$ ) as a function of $\mathrm{pH}$ spectra of the as-prepared $\mathrm{Ca}_{9} \mathrm{Mg}_{1} \mathrm{HAp}$ $\mathrm{GA}(n)\left(\mathrm{n}=10\right.$ and 20) and sample $\mathrm{Ca}_{9} \mathrm{Mg}_{1} \mathrm{HAp}$. (B) Number of protons consumed by the surface for different samples reported in $\mu \mathrm{mol} / \mathrm{m}^{2}$ during their 2 hours immersion in a solution containing $0.1 \mathrm{M}$ $\mathrm{NaCl}+\mathrm{HCl}$ or $\mathrm{NaOH}$ as a function of $\mathrm{pH}$ of the as-prepared $\mathrm{Ca}_{9} \mathrm{Mg}_{1} \mathrm{HAp}-\mathrm{GA}(n)(\mathrm{n}=10$ and 20) and sample $\mathrm{Ca}_{9} \mathrm{Mg}_{1} \mathrm{HAp}$.

\subsubsection{Proposed glutamic acid sorption mechanism}

The IR spectra provide data about the ionization state of the carboxylate groups grafted onto the apatite surface. Indeed, the presence of bands characteristic of $-\mathrm{COO}^{-}$groups and the absence of bands attributed to $\mathrm{COOH}$ groups $\left(1700 \mathrm{~cm}^{-1}\right)$ indicate the carboxylate form. This shows that the interaction is mainly due to the electrostatic interaction between - $\mathrm{COO}^{-}$groups of the glutamic acid and the calcium $\mathrm{Ca}^{2+} / \mathrm{Mg}^{2+}$ ions of the hydroxyapatite. We cannot exclude also that interactions between $\mathrm{COO}^{-}$and surface $\mathrm{POH}$ groups are possible. The fixation is due to the simultaneous presence of $-\mathrm{COO}-/ \mathrm{Ca}^{2+} / \mathrm{Mg}^{2+}$ electrostatic interactions and $\mathrm{H}$-bonds between $\mathrm{NH}_{3}{ }^{+}$protons and surface oxygen atoms of the $\mathrm{PO}_{4}$ group $[55,56]$.

The nature of interactions between the apatite surface and a glutamic acid depends on the $\mathrm{pH}$ value of the medium. Taking into consideration that the reaction is carried out at a $\mathrm{pH}$ above 9.5, we 
can consider that in aqueous solution glutamic acid exists as a carboxylate ion, the amino group being

neutral [57]. Under the same conditions, the apatite surface is considered as negatively charged, therefore some authors consider that the electrostatic interactions between the surface and the aminoacid are very weak $[58,59]$. In the present study, glutamic molecules are present in the form of carboxylate ions, which can lead to calcium complexes that participate in the formation of the crystalline edifice. The observation of the IR spectra, showing characteristic vibrations of carboxylate salts, lead us to conclude that the amino-acid in this carboxylate ionic form exchanges an hydroxyl ion. Different model grafting mechanisms proposed based on the results obtained are shown in scheme 1.

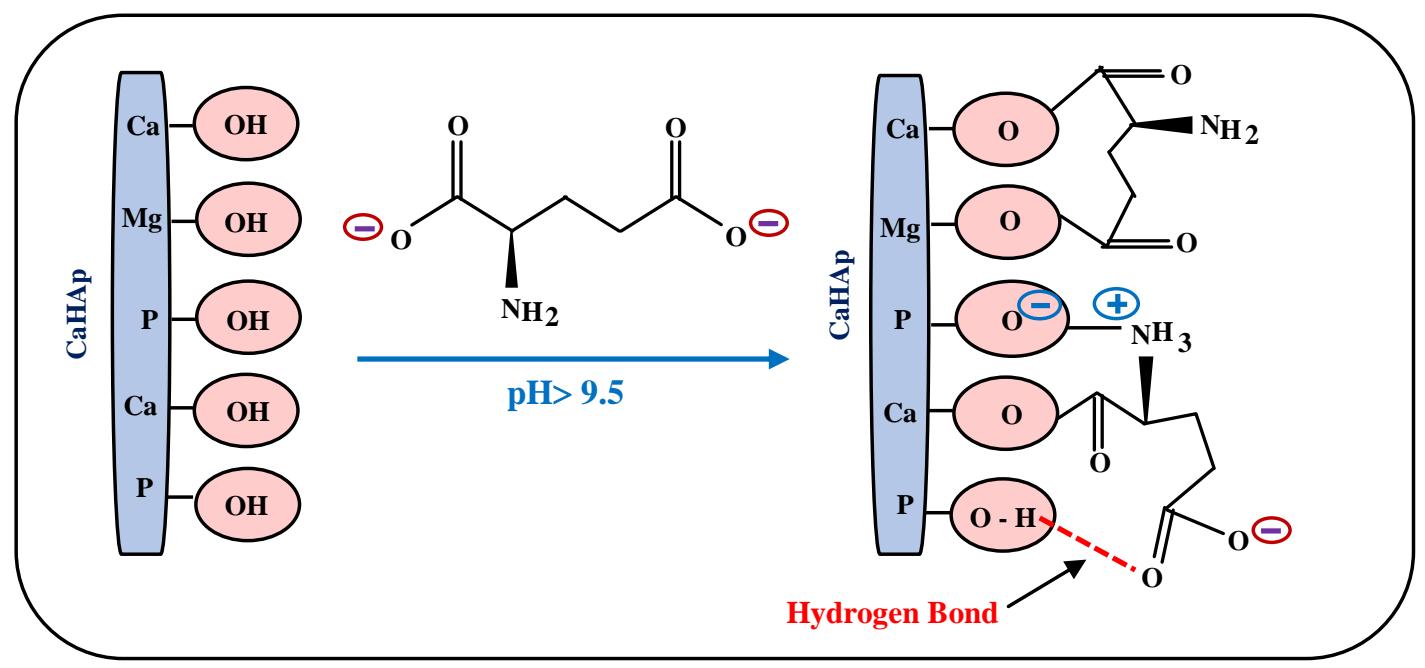

Scheme 1. Formation of Ca carboxylate salt leading to the grafting of glutamic on the CaHAp surface.

\section{Conclusion}

In conclusion, we have successfully synthesized hydroxyapatite-glutamic composites of different glutamic acid content using the hydrothermal method. The presence of the glutamic acid and/or magnesium in the reaction solution does not change the apatite structure, but reduces the crystallinity and the crystallite sizes. According to IR spectroscopy, the new vibrations after adsorption can be attributed to those of the organic moieties grafted on calcium or magnesium atoms onto the surface of the apatite. TEM images confirm the reduction of crystallite sizes and indicate the change in its morphology. 


\section{Acknowledgments}

This research was carried out with the financial support of the University of Monastir, (Tunisia); the University Pierre and Marie Curie and CNRS (France).

\section{References}

[1] J.C. Elliot, Structure and Chemistry of the Apatites and Other Calcium Orthophosphates, Elsevier, Amsterdam, 1994.

[2] D. Govindaraj, M. Rajan, M. A. Munusamy, A. A. Alarfaj, A. Higuchi, S. S. Kumar, Carbon nanotubes/pectin/minerals substituted apatite nanocomposite depositions on anodized titanium for hard tissue implant: In vivo biological performance, Mater. Chem. Phys. 194 (2017) 77-89.

[3] J. Gomez-Morales, M. Lafisco, J. M. Delagado-Lopez, S. Sarda, C. Drouet, Progress on the preparation of nanocrystalline apatites and surface characterization : overview of fundamental and applied aspects, Progr. Cryst. Growth Charact. Mater. 59 (2013) 1-46.

[4] S. Ben Moussa, J. Lachheb, M. Gruselle, B. Maaten, K. Kriis, T. Kangerd, K. Tõnsuaadu, B. Badraoui, Calcium, Barium and Strontium Apatites: A New Generation of Catalysts in the Biginelli Reaction, Tetrahedron 73 (2017) 6542-6548.

[5] M. Gruselle, Apatites: a new family of catalysts in organic synthesis, J. Organomet. Chem. 793 (2015) 93-101.

[6] M. Wang, R. Qian, M. Bao, C. Gu, P. Zhu, Raman, FT-IR and XRD study of bovine bone mineral and carbonated apatites with different carbonate levels, Mater. Lett. 210 (2018) 203-206.

[7] N. Kanwal, D. S. Brauer, J. Earl, R. M. Wilson, N. Karpukhina, R. G. Hill, In-vitro apatite formation capacity of a bioactive glass - containing toothpaste, J. Dent. 68 (2018) 51-58.

[8] N.V. Bulina, M. V. Chaikina, I. Y. Prosanov, D. V. Dudina, L. A.S olovyov, Fast synthesis of Lasubstituted apatite by the dry mechanochemical method and analysis of its structure, J. Solid State Chem. 252 (2017) 93-99.

[9] P.N. Lim, T. Konishi, Z. Wang, J. Feng, L. Wang, J. Han, Z. Yang, E.S. Thian, Enhancing osteoconductivity and biocompatibility of silver-substituted apatite in vivo through silicon cosubstitution, Mater. Lett. 212 (2018) 90-93.

[10] A. Hamad, B. Badraoui, M. Debbabi, Synthèse et étude physico-chimique de fluoroapatites mixtes à cations bivalents $\mathrm{Pb}-\mathrm{Cd}, \mathrm{Pb}-\mathrm{Sr}$ et Sr-Cd, J. Soc. Chim. Tunisie. 5 (2003) 115-124.

[11] S. Ben Moussa, M. Laajimi, R. Ben Chaâbane, B. Badraoui, M. Gruselle, A. Laghzizil, Synthesis, Rietveld refinements and electrical conductivity of news fluorobritholite based on lead $\mathrm{Ca}_{7}$ ${ }_{x} \mathrm{~Pb}_{\mathrm{x}} \mathrm{La}_{3}\left(\mathrm{PO}_{4}\right)_{3}\left(\mathrm{SiO}_{4}\right)_{3} \mathrm{~F}_{2}(0 \leq \mathrm{x} \leq 2)$, J. Mol. Struct. 1147 (2017) 114-120. 
[12] K .Kaur, K. J. Singh, V. Anand, N. Islam, G. Bhatia, N. Kalia, J. Singh, Lanthanide (= Ce, Pr, Nd

and $\mathrm{Tb}$ ) Ions Substitution at Calcium Sites of Hydroxyl Apatite Nanoparticles as Fluorescent Bio Probes: Experimental and Density Functional Theory Study, Ceram. Int. 43 (2017) 10097-10108.

[13] B. Badraoui, A. Aissa, A. Bigi, M. Gazzano, Synthesis and characterization of $\operatorname{Sr}_{(10-\mathrm{x})} \mathrm{Cd}_{\mathrm{x}}\left(\mathrm{PO}_{4}\right)_{6} \mathrm{Y}_{2}$ ( $\mathrm{Y}=\mathrm{OH}$ and F): A comparison of apatites containing two divalent cations, Mater. Res. Bull. 44 (2009) $522-530$.

[14] A. Aissa, B. Badraoui, R. Thouvenot, M. Debbabi, Synthesis, X-ray Structural Analysis and Spectroscopic Investigations (IR and ${ }^{31} \mathrm{P}$ MAS NMR) of Mixed Barium/Strontium Fluoroapatites, Eur. J. Inorg. Chem. 19 (2004) 3828-3836.

[15] Z. Geng, Z. Cui, Z. Li, S. Zhu, Y. Liang, W. Weijia Luc, X. Yang, Synthesis, characterization and the formation mechanism of magnesium- and strontium-substituted hydroxyapatite, J. Mater. Chem. B 3 (2015) 3738-3746.

[16] Z. Geng, R. Wang, Z. Li, Z. Cui, S. Zhu, Y. Liang, Y. Liu, B. Huijing, X. Li, Q. Huo, Z. Liu, X. Yang, Synthesis, characterization and biological evaluation of strontium/magnesium-co-substituted hydroxyapatite, J. Biomater. Appl. 31 (2016) 140-151.

[17] Z. Gu, S. Wang, W. Weng, X. Chen, L. Cao, J. Wei, J. W. Shin, J. Su, Influences of doping mesoporous magnesium silicate on water absorption, drug release, degradability, apatitemineralization and primary cells responses to calcium sulfate based bone cements, Mater. Sci. Eng. C 75 (2017) 620-628.

[18] A. Bigi, E. Foresti, R. Gregorini, A. Ripamonti, N. Roveri, J. S. Shah, Structural and chemical characterization of inorganic deposits in calcified human mitral valve, Calcif. Tissue Int. 50 (1992) 439-444.

[19] J. M. Burnell, E.J. Teubner, A.G. Miller, Normal maturational changes in bone matrix, mineral, and crystal size in the rat, Calcif. Tissue Int. 31 (1980) 9-13.

[20] M. Li, X. Liu, Z. Xu, K.W.K. Yeung, S. Wu, Dopamine Modified Organriorganic Hybrid Coating for Antimicrobial and Osteogenesis, ACS Appl. Mater. Interfaces 8 (2016) 33972-33981.

[21] W.Z. Yu, Y. Zhang, X. Liu, Y. Xiang, Z. Li , S. Wu, Synergistic antibacterial activity of multi components in lysozyme/chitosan/silver/hydroxyapatite hybrid coating, Materials \& Design 139 (2018) 351-362.

[22] Y. Hong, H. Fan, B. Li, B.Guo, M. Liu, X. Zhang, Fabrication, biological effects, and medical applications of calcium phosphate nanoceramics, Mater. Sci. Eng. R. 70 (2010) 225-242. 
[23] S. Padilla, I. Izquierdo-Barba, M. Vallet-Regi, High Specific Surface Area in Nanometric Carbonated Hydroxyapatite, Chem. Mater. 20 (2008) 5942-5944.

[24] S. Sanchez-Salcedo, F. Balas, I. Izquierdo-Barba, M. Vallet-Regi, In vitro structural changes in porous HA/ $\beta$-TCP scaffolds in simulated body fluid, Acta Biomater. 5 (2009) 2738-2751.

[25] H. Zhou, J. Lee, Nanoscale hydroxyapatite particles for bone tissue engineering, Acta Biomater. 7 (2011) 2769-2781.

[26] R.G. Carrodeguas, S. De Aza, $\alpha$-Tricalcium phosphate: synthesis, properties and biomedical applications, Acta Biomater. 7 (2011) 3536-3546.

[27] A. Bigi, G. Falini, E. Foresti, M. Gazzano, A. Ripamonti, N. Roveri, Magnesium influence on hydroxyapatite crystallization, J. Inorg. Biochem. 49 (1993) 69-78.

[28] A. Bigi, E. Boanini, M. Gazzano, M.A. Kordecki, K. Rubini, Microstructural investigation of hydroxyapatite-polyelectrolyte composites, J. Mater. Chem. 14 (2004) 274-279.

[29] PANalyticalX'PertHigth Score Plus version 2.0.

[30] L. Wu, F. Willis, P.W. Schindler, Surface complexation of calcium minerals in aqueous solution. J. Colloid Interf. Sc. 147 (1991) 178-185.

[31] E. Castiglioni, P. Biscarini, S. Abbate, Experimental Aspects of Solid State Circular Dichroism, Chirality 21 (2009) 28-36.

[32] L. Pauling, The Nature of the Chemical Bond, 3rd Ed., p. 93. Cornell University Press, New York (1960).

[33] M. Othmani, A. Aissa, H. Bachoua, M. Debbabi, Surface modification of calcium-copper hydroxyapatites using polyaspartic acid, Appl. Surf. Sci. 264 (2013) 886-891.

[34] T. Turki, M. Othmani, C. Goze Bac, F. Rachdi, K. Bouzouita, Surface modification of zinccontaining hydroxyapatite by tartaric acid, Appl. Surf. Sci. 284 (2013) 66- 71.

[35] A. Yasukawa, S. Ouchi, K. Kandori, T. Ishikawa, Preparation and characterization of magnesiumcalcium hydroxyapatites, J. Mater. Chem. 6 (1996) 1401-1405.

[36] S. Diallo-Garcia, D. Laurencin, J.M. Krafft, S. Casale, M. E. Smith, H. Lauron-Pernot, G. Costentinn, Influence of Magnesium Substitution on the Basic Properties of Hydroxyapatites, J. Phys. Chem. C 115 (2011) 24317-24327.

[37] M. Ben Osman, S. Diallo Garcia, J.M. Krafft, C. Méthivier, J. Blanchard, T. Yoshioka, J. Kubo, G. Costentin, Control of calcium accessibility over hydroxyapatite by post-precipitation steps: influence on the catalytic reactivity toward alcohols, Phys. Chem. Chem. Phys. 18 (2016) 2783727847.

[38] S. Nakamura, H. Takeda, K. Yamashita, Proton Transport Polarization and Depolarization of Hydroxyapatite Ceramics, J. Appl. Phys. 89 (2001) 5386- 5392. 
[39] S. Ben Moussa, H. Bachouâ, M. Gruselle, P. Beaunier, A. Flambard, B. Badraoui, Hybrid organic-inorganic materials based on hydroxyapatite structure, J. Solid. Stat. Chem. 248 (2017) 171177.

[40] M. Rinaudo, A.Domard, Circular dichroism studies on alpha.-L-glutamic acid oligomers in solution, J. Amer. Chem. Soc. 98 (1976) 6360-6364.

[41] J.T. Navarrete, V. Hernandez, F.J. Ramirez, Vibrational study of aspartic acid and glutamic acid dipeptides, J. Mol. Struct. 348 (1995) 249-252.

[42] J.V. Garcia-Ramos, P. Carmouna, A. Hidalgo, The adsorption of acidic amino acids and homopolypeptides on hydroxyapatite, J. Colloid Interf. Sci. 83 (1981) 479-484.

[43] H. Bachoua, G. Renaudin, B. Badraoui, F. Leroux, M. Debbabi, J. Marie Nedelec, Preparation and characterization of functionalized hybrid hydroxyapatite from phosphorite and its potential application to $\mathrm{Pb}^{2+}$ remediation, J. Sol-Gel. Sci. Technol.78 (2016) 621-631.

[44] A. A. Chaudhry, J. Goodall, M. Vickers, J.K. Cockcroft, I. Rehman, J.C. Knowles, J.A. Darr, Synthesis and characterization of magnesium substituted calcium phosphate bioceramic nanoparticles made via continuous hydrothermal flow synthesis, J. Mater. Chem., 18 (2008) 5900-5908.

[45] R.N. Correia, M.C.F. Magalhães, P.A.A.P. Marques, A.M.R. Senos, Wet synthesis and characterization of modified hydroxyapatite powders, J. Mater. Sci: Mater. Med, 7 (1996) 501-505.

[46] A. Bigi, E. Boanini, C. Cappuccini, M. Gazzano, Strontium-substituted hydroxyapatite nanocrystals, Inorg. Chim. Acta 360 (2007) 1009-1016.

[47] F. Ren, R. Xin, X. Ge, Y. Leng, Characterization and structural analysis of zinc-substituted hydroxyapatites, Acta. Biomater. 5 (2009) 3141-3149.

[48] E. Boanini, P. Torricelli, M. Gazzano, R. Giardino, A. Bigi, Nanocomposites of hydroxyapatite with aspartic acid and glutamic acid and their interaction with osteoblast-like cells, Biomater. 27 (2006) 4428-4433.

[49] O. G. Silva, E C. F Silva, M. G. Fonseca, N. H. Luiza, A. C. Arakaki, Hydroxyapatite organofunctionalized with salivating agents to heavy cation removal, J. Colloid Interf. Sci. 302 (2006) 485491.

[50] V. O. Kollath, F. V. den Broeck, K. Fehér, J.C. Martins, J. Luyten, K. Traina, S. Mullens, R. Cloots, A Modular Approach To Study Protein Adsorption on Surface Modified Hydroxyapatite, Chem. Eur. J. 21 (2015) 10497-10505.

[51] L. C. Bell, A. M. Posner, J. P. Quirck, The point of zero charge of hydroxyapatite and fluorapatite in aqueous solutions, J. Colloid Interf. Sci. 42 (1973) 250-261.

[52] Y. A. Attia, D.W. Fuerstenau, The equilibrium composition of hydroxyapatite and fluoroapatite water interfaces, Colloid Surf. 34 (1988) 271-285. 
[53] F. Z. Saleeb, P.L. De Bruyn, Surface properties of alkaline earth apatites, J. Electroanal. Chem. 37 (1972) 99-118.

[54] L. Wu, W. Forsling, P.W. Schindler, Surface complexation of calcium minerals in aqueous solution, J. Colloid Interf. Sci. 147 (1991) 178-185.

[55] N. Almora-Barrios, K. F. Austen, N. H de Leeuw, Density functional theory study of the binding of glycine, proline, and hydroxyproline to the Hydroxyapatite (001) and (010) surfaces. Langmuir 25 (2009) 5018-5025.

[56] A. Rimola, M. Corno, C. Zicovich-Wilson, P. Ugliengo, Ab initiomodelling of protein/biomaterial interactions: glycine adsorption at hydroxyapatite surfaces. J. Am. Chem. Soc. 130 (2008) 181-183.

[57] William H. Brown and Lawrence S. Brown (2008), Organic Chemistry (5th edition). Page 1041.

[58] B. Palazzo, D. Walsh, M. Iafisco, E. Foresti, L. Bertinetti, G. Martra, C.L. Bianchi, G. Cappelletti, N. Roveri, Amino acid synergetic effect on structure, morphology and surface properties of biomimetic apatite nanocrystals, Acta Biomater. 5 (2009) 1241-1252

[59] P.W. Brown, R. I. Martin, An analysis of hydroxyapatite surface layer formation, J. Phys. Chem. B 103 (1999) 1671-1675. 